\title{
PENERAPAN METODE PICTURE EXCHANGE COMMUNICATION SYSTEM (PECS) TERHADAP KETERAMPILAN KOMUNIKASI ANAK SPEKTRUM AUTISME
}

\author{
Qibti 'Inayatul Arfi \\ Pendidikan Luar Biasa, Fakultas Ilmu Pendidikan, Universitas Negeri Surabaya \\ qibti.17010044062@mhs.unesa.ac.id \\ Febrita Ardianingsih \\ Pendidikan Luar Biasa, Fakultas Ilmu Pendidikan, Universitas Negeri Surabaya \\ febritaardianingsih@unesa.ac.id
}

\begin{abstract}
Abstrak
Anak spektrum autisme merupakan salah satu individu yang memiliki hambatan keterampilan komunikasi dan membutuhkan suatu metode untuk meningkatkan keterampilan komunikasinya. Metode Picture Exchange Commununication System (PECS) merupakan salah satu best practice untuk mengembangkan keterampilan komunikasi anak spektrum autism. Penelitian ini bertujuan untuk mendeskripsikan tentang penerapan metode Picture Exchange Commununication System (PECS) terhadap keterampilan komunikasi anak spektrum autisme. Jenis penelitian ini adalah kuantitatif deskriptif dengan desain berupa penelitian survei. Sampel penelitian terdiri atas 38 guru, terapis, atau orang yang berkompeten dalam pengembangan keterampilan komunikasi anak spektrum autisme di wilayah Provinsi Jawa Timur melalui penyebaran kuisioner menggunakan google form. Uji validitas dan reliabilitas menggunakan SPSS, sedangkan data penelitian dianalisis secara deskriptif kuantitatif menggunakan persentase. Hasil penelitian menunjukkan bahwa: guru dan terapis di Jawa Timur yang telah menerapkan metode PECS sebesar 79\%. Sebagian besar guru dan terapis tersebut sudah menerapkan PECS fase ke-1 sampai fase ke-6 sesuai tahapanannya dan merasa PECS sesuai dengan anak spektrum autism serta dapat meningkatkan keterampilan komunikasinya.
\end{abstract}

Kata Kunci: anak spektrum autisme, metode PECS, keterampilan komunikasi anak spektrum autisme.

\begin{abstract}
Children with autism spectrum are one of the individuals who have communication skills barriers and need a method to improve their communication skills. The Picture Exchange Communication System (PECS) method is one of the best practices for developing communication skills for children with autism spectrum. This study aims to describe the application of the Picture Exchange Communication System (PECS) method to the communication skills of children with autism spectrum. This type of research is quantitative descriptive with a survey research design. The research sample consisted of 38 teachers, therapists, or people who are competent in developing communication skills for autism spectrum children in East Java Province through the distribution of questionnaires using google forms. Test the validity and reliability using SPSS, while the research data were analyzed quantitatively using percentages. The results showed that: $79 \%$ of teachers and therapists in East Java had applied the PECS method. Most of the teachers and therapists have implemented PECS phase 1 to phase 6 according to their stages and feel that PECS is suitable for children on the autism spectrum and can improve their communication skills.
\end{abstract}

Keywords: autism spectrum, PECS methods, communication skills of autism spectrum. 


\section{PENDAHULUAN}

Manusia adalah makhluk sosial yang membutuhkan komunikasi dengan manusia lain. Perkembangan fenomena komunikasi tidak hanya pesat dalam bidang komunikasi massa, melainkan juga berkembang dalam ranah komunikasi interpersonal maupun kelompok. Untuk kelangsungan hidupnya, manusia membutuhkan komunikasi dan interaksi secara intens dengan sesama sebab interaksi merupakan fondasi utama manusia untuk belajar. Permasalahan dalam komunikasi seringkali dianggap sebagai hambatan individu maupun kelompok.

Anak spektrum autisme memiliki gangguan perkembangan dalam fungsi otak atau neurodevelopmental. Gangguan ini dapat menyebabkan hambatan dalam interaksi sosial, komunikasi secara verbal dan non-verbal, dan perilaku dan minat anak terbatas (Asep Sunandar et al., 2019). Anak spektrum autisme memiliki hambatan interaksi sosial, pengucapan bahasa yang digunakan dalam komunikasi sosial, dan imanijatif terhadap sesuatu (Ritonga \& Hasibuan, 2016). Pengucapan komunikasi verbal secara spontan anak autisme terbatas hanya sekitar 5 sampai maksimum 20 kata (Rega et al., 2018). Anak autis memiliki gangguan kualitatif dalam komunikasi yang dipengaruhi oleh gangguan perkembangan neurobiologis. Adanya gangguan ini berpengaruh terhadap komunikasi, proses belajar anak, dan hubungan interaksi sosialnya (Heryati \& Ratnengsih, 2017). Anak spektrum autisme cenderung menggunakan komunikasi non-verbal daripada komunikasi verbal. Dalam hal ini, anak autis menggunakan komunikasi dengan orang lain dengan cara menangis atau berteriak untuk memenuhi keinginannya (Marhamah, 2019). Selain itu, DSM V dalam Wiggins et al., (2019) menyatakan bahwa anak spektrum autisme memililiki hambatan dalam komunikasi dan interaksi sosial serta terbatas pada perilaku minat, aktivitas berulang, dan steorotip

Berdasarkan paparan di atas, maka diperlukan strategi yang tepat untuk membantu masalah hambatan komunikasi anak spektrum autisme yaitu komunikasi augmentatif dan alternatif. Komunikasi augmentatif dan alternatif dapat menggunakan alat bantu dan tanpa bantuan (gerakan tubuh). Alat bantu yang digunakan dalam proses komunikasi dengan anak dengan spektrum autisme dengan menggunakan gambar, simbol, tulisan kata, dan buku (Alsayedhassan et al., 2016). Selain itu, kemampuan daya ingat visual anak spektrum autisme lebih baik dan mudah dalam menerima informasi dengan visualisasi. Media visualisasi yang digunakan dapat berupa gambar, foto, atau tulisan kata (Koesdiningsih et al., 2019).

Metode Picture Exchange Communication System (PECS) termasuk komponen pendekatan dalam komunikasi augmentatif dan alternatif. Metode PECS menggunakan alat bantuan berupa pertukaran simbol atau gambar. Dalam metode PECS terdapat enam fase dalam pelaksanaannya. Dari anak spektrum autisme yang sulit dalam berkomunikasi dan berinteraksi dengan orang lain diberikan gambar atau simbol dan diminta memilih yang dia sukai sampai anak dapat memberikan pendapat dari suatu gambar (Alsayedhassan et al., 2016). Metode PECS mengajarkan kepada anak spektrum autisme untuk berlatih komunikasi secara terstruktur dan displin (Jurgens et al., 2019). Media yang digunakan dalam metode PECS menggunakan warna yang mencolok agar menarik perhatian anak spektrum autisme (Asep Sunandar et al., 2019).

Menurut Goa \& Derung (2017), metode Picture Exchange Communication System (PECS) mempunyai enam fase, yaitu. (1) Tahap pertama yaitu fase latihan dalam berkomunikasi. Dalam tahap ini, anak diberikan sebuah gambar yang disukai kemudian diminta untuk meletakkannya ke tangan pendamping atau teman yang berada di sekitarnya dan ditukar dengan benda/aktivitas 
sebenarnya; (2) Tahap kedua yaitu fase jarak, kemauan yang kuat, dan ketekunan. Fase kedua, anak diminta untuk mengambil buku atau gambar yang disukainya yang sudah diatur jaraknya untuk diletakkan ke pendampingnya dan ditukar dengan benda/aktivitas sebenarnya; (3) Tahap ketiga yaitu fase membedakan sesuatu. Fase ketiga ini, anak diminta untuk mengambil dan memberikan satu gambar dari beberapa gambar yang akan diberikan kepada pendampingnya dan ditukar dengan benda/aktivitas sebenarnya. (4) Tahap keempat yaitu fase pembentukan struktur kalimat pada anak. Anak diharapkan dapat menyusun kalimat dengan menggabungkan kata "saya mau" dengan ditambah bantuan gambar pada buku komunikasi dan kemudian diserahkan kepada pendamping untuk ditukar dengan benda/aktivitas sebenarnya. (5) Tahap kelima yaitu memberikan respon terhadap pertanyaan. Anak dapat menjawab pertanyaan dari pendamping tentang "apa yang kamu mau?" dan secara spontan menyusun kalimat di buku PECSnya sesuai dengan yang diinginkannya. Kemudian menyerahkan kalimat tersebut kepada pendamping untuk ditukar dengan benda/aktivitas yang sebenarnya. (6) Tahap keenam yaitu fase memberikan komentar terhadap sesuatu. Tahap ini anak dapat menyusun kalimat dari pertanyaan di buku PECS, misalkan "saya lihat bola" kemudian diberikan ke pendamping yang bertanya. Pendamping dapat memberikan pertanyaan yang bervariasi seperti "kamu sedang apa?" atau "kamu lihat apa?" agar anak dapat berlatih menguraikan sebuah kalimat permulaan yang berbeda. Perlu diperhatikan bahwa jika anak memberikan respon sesuai yang diperintahkan pada tiap fase, berikanlah hadiah atau pujian sesuai dengan kesukaannya.

Metode PECS dapat diterapkan di sekolah khusus, sekolah inklusi, maupun lembaga terapi autis. Menurut Daroni et al., 2018, sekolah khusus yaitu sekolah yang menggunakan program individual atau IEP (Individual Educational Program). Pelaksanaan program pendidikan menyesuaikan dengan kebutuhan serta kemampuan yang dimiliki anak agar kemampuan perkembangannya dapat maksimal. Sedangkan sekolah inklusi dalam pelaksanaanya hampir sama dengan sekolah reguler, tetapi yang membedakan yaitu adanya keberadaan siswa berkebutuhan khusus di dalam kelas untuk memberikan edukasi penanaman karakter siswa, seperti saling menghargai, peduli, dan kerja sama (Amka, 2017).

Metode PECS telah terbukti efektif dapat meningkatkan keterampilan komunikasi anak spektrum autisme dan diakui secara luas sebagai salah satu best practice, termasuk juga di Indonesia. Beberapa penelitian yang mendukung adalah sebagai berikut. Terdapat penelitian di unit terapi Bhakti Luhur yang menerapkan metode PECS terhadap 4 anak spektrum autisme. Dalam penelitian tersebut, terdapat peningkatan pada keterampilan komunikasinya dibuktikan dengan kenaikan nilai dari pre-test ke post-test yang lebih baik setelah diberikan metode PECS. Komunikasi ekspresif menjadi nilai tertingginya (Goa \& Derung, 2017). Selain itu, terdapat penelitian di SLB-C Asih Manunggal untuk anak dengan spektrum autisme yang menunjukkan adanya pengaruh terhadap peningkatan kemampuan komunikasi. Penelitian ini ditunjukkan dengan adanya peningkatan dari kemampuan awal sampai setelah diberikan intervensi menggunakan metode PECS (Heryati \& Ratnengsih, 2017). Di SLB Cinta Mandiri Lhokseumawe menganggap bahwa metode PECS cocok diterapkan untuk melatih kefokusan serta mengembangkan keterampilan anak spektrum autisme dikarenakan menggunakan gambar dalam alat bantu proses penerapannya (Marhamah, 2019).

Walaupun terbukti efektif, namun belum diketahui data tentang bagaimana penerapan metode PECS dalam peningkatan keterampilan komunikasi anak spektrum autis di sekolah inklusi, sekolah khusus, serta lembaga terapi khususnya wilayah Jawa Timur Provinsi. Oleh karena itu penelitian ini bertujuan untuk mengetahui penerapan Metode PECS terhadap keterampilan 
komunikasi anak spektrum autis. Beberapa rumusan masalah penelitian ini sebagai berikut. (1) Berapa banyak guru dan terapis di Jawa Timur yang telah menerapkan metode PECS? (2) Apakah semua fase PECS sudah diterapkan oleh guru dan terapis di Jawa Timur sesuai dengan prosedur dan tahapannya? (3) Apakah metode PECS sesuai dan dapat meningkatkan keterampilan komunikasi anak spektrum autis di Jawa Timur? (4) Apakah ada kendala dalam penerapan metode PECS di Jawa Timur? (5) Dalam penerapan metode PECS, apakah guru dan terapis di Jawa Timur memberikan rewards dan hukuman?

\section{METODE}

\section{Desain dan Jenis Penelitian}

Penelitian ini adalah deskriptif kuantitatif. Penelitian deskriptif yaitu penelitian yang mendeskripsikan data atau sampel yang tekumpul dengan apa adanya dan tidak membuat kesimpulan (Sugiyono, 2016:147). Penelitian kuantitatif yaitu penelitian yang menggunakan populasi atau sampel tertentu, instrumen penelitian, analisis data yang bersifat kuantitatif untuk menguji hipotesis yang telah ditetapkan serta berlandaskan filsafat positivisme (Sugiyono, 2016:8). Desain penelitian ini berupa penelitian survei, yaitu penelitian yang dilakukan untuk mendapatkan data dari tempat tertentu secara alamiah, bukan buatan diantaranya dengan cara mengedarkan kuesioner, melakukan tes, atau wawancara (Sugiyono, 2016:6).

\section{Populasi dan Sampel}

Populasi penelitian ini adalah guru dan terapis yang mengajarkan atau mengembangkan keterampilan komunikasi anak spektrum autisme pada sekolah inklusi, sekolah khusus, serta lembaga terapi di Jawa Timur. Teknik pengambilan sampel berupa Purposive Sampling yaitu berdasarkan kriteria yang sesuai dengan subjek penelitian seperti berada di wilayah Jawa Timur dan mengajarkan keterampilan komunikasi anak spektrum autisme. Jumlah sampel penelitian ini sebanyak 38 orang, yang terdiri 27 guru SLB (71\%), 6 guru inklusi (16\%), 4 orang terapis autis (10\%), dan 1 orang shadow teacher $(3 \%)$.

\section{Variabel dan Indikator}

Penelitian ini dlaksanakan untuk mengetahui bagaimana penerapan metode PECS secara umum di wilayah Jawa Timur. Indikator dalam penelitian ini berupa 15 pernyataan dicantumkan ke dalam google form berupa kuisioner yang akan diisi oleh guru, terapis, ataupun orang yang berpengalaman dalam mengembangkan keterampilan komunikasi anak spektrum autisme. Pengisian kuisioner dilaksanakan selama satu minggu dari 21-28 Februari 2021. Variabel dan indikator dalam penelitian ini dinyatakan pada tabel berikut ini.

Tabel 1. Variabel dan Indikator Penelitian

\begin{tabular}{|c|c|l|}
\hline Variabel & Indikator & \multicolumn{1}{|c|}{ Pernyataan } \\
\hline & P1 & Saya memiliki pemahaman teknis tentang tahapan metode PECS. \\
\cline { 2 - 4 } & P2 & $\begin{array}{l}\text { Saya menerapkan fase atau tahapan PECS pertama yaitu latihan } \\
\text { berkomunikasi tahap awal yaitu menukarkan kartu pada benda. }\end{array}$ \\
\cline { 2 - 4 } \begin{tabular}{c} 
Penerapan $\begin{array}{c}\text { Metode } \\
\text { PECS }\end{array}$ \\
\cline { 2 - 4 }
\end{tabular} & P3 & $\begin{array}{l}\text { Saya menerapkan fase atau tahapan PECS kedua yaitu memberikan } \\
\text { jarak dan adanya persistensi atau komunikasi berulang dalam } \\
\text { menukarkan gambar dengan benda. }\end{array}$ \\
\hline P4 & $\begin{array}{l}\text { Saya menerapkan fase atau tahapan PECS ketiga (a) yaitu } \\
\text { membedakan dua benda atau gambar yang disukai dan tidak disukai } \\
\text { dalam berkomunikasi untuk mendapatkan benda. }\end{array}$ \\
\hline
\end{tabular}




\begin{tabular}{|c|c|c|}
\hline Variabel & Indikator & Pernyataan \\
\hline & P5 & $\begin{array}{l}\text { Saya menerapkan fase atau tahapan PECS ketiga (b) yaitu } \\
\text { membedakan dua gambar benda atau gambar yang sama-sama disukai } \\
\text { dalam berkomunikasi untuk mendapatkan benda. }\end{array}$ \\
\hline & P6 & $\begin{array}{l}\text { Saya menerapkan fase atau tahapan PECS keempat yaitu } \\
\text { pembentukkan struktur kalimat pada anak untuk mendapatkan benda. }\end{array}$ \\
\hline & P7 & $\begin{array}{l}\text { Saya menerapkan fase atau tahapan PECS kelima yaitu memberikan } \\
\text { kesempatan kepada anak merespon pertanyaan seperti "Apa yang } \\
\text { kamu inginkan?" dengan membentuk struktur kalimat dalam } \\
\text { berkomunikasi untuk mendapatkan benda. }\end{array}$ \\
\hline & P8 & $\begin{array}{l}\text { Saya menerapkan fase atau tahapan PECS keenam yaitu memberikan } \\
\text { kesempatan untuk siswa berkomentar terhadap sesuatu yang dilihatnya } \\
\text { atau suatu pernyataan. }\end{array}$ \\
\hline & P9 & Saya melaksanakan prosedur metode PECS sesuai dengan tahapannya. \\
\hline & P10 & $\begin{array}{l}\text { Saya merasa metode ini cocok diterapkan untuk mengembangkan } \\
\text { keterampilan komunikasi anak spektrum autime. }\end{array}$ \\
\hline & P11 & $\begin{array}{l}\text { Berdasarkan pengalaman saya, metode PECS dapat meningkatkan } \\
\text { keterampilan komunikasi anak spektrum autisme. }\end{array}$ \\
\hline & P12 & $\begin{array}{l}\text { Saya merasa tidak ada kendala dalam pemberian metode PECS untuk } \\
\text { anak spektrum autisme. }\end{array}$ \\
\hline & P13 & $\begin{array}{l}\text { Saya merasa alat bantu media } \\
\begin{array}{l}\text { visualisasi untuk penerapan metode } \\
\text { PECS mudah ditemukan dan harga terjangkau }\end{array} \\
\text { tanda, gambar, dan/atau simbol. }\end{array}$ \\
\hline & P14 & $\begin{array}{l}\text { Saya selalu memberikan reward berupa hadiah kepada anak setelah } \\
\text { melakukan apa yang diperintahkan. }\end{array}$ \\
\hline & P15 & $\begin{array}{l}\text { Saya memberikan punishment atau hukuman seperti tidak memberikan } \\
\text { sesuatu yang disu kai saat anak tidak mengikuti apa yang } \\
\text { diperintahkan. }\end{array}$ \\
\hline
\end{tabular}

\section{HASIL DAN PEMBAHASAN}

\section{A. HASIL}

\section{Uji Instrumen}

Uji instrumen penelitian yang dilakukan dalam penelitian ini adalah uji validitas dan uji reabilitas. Uji validitas digunakan untuk mengetahui keabsahan suatu penelitian tersebut tepat dalam pengambilan datanya. Uji validitas dalam penelitian ini menggunakan uji korelasi bivariat Spearman's Rho dengan menggunakan SPSS versi 23 for Windows. Penelitian pendidikan menggunakan nilai signifikan 0,05 atau $5 \%$ dengan perolehan uji validitas dikatakan valid jika harga $r$ hitung lebih besar dari $r$ tabel serta derajat kebebasan (dk) merupakan hasil dari jumlah responden dikurangi dua $(\mathrm{dk}=\mathrm{n}-2)$ (Yusup, 2018). Peneliti menyebarkan kuisioner dan mendapatkan 38 responden, maka $\mathrm{dk}=35-2$ atau $\mathrm{dk}=33$ dengan alpha $(5 \%=0,05)$ jadi $\mathrm{r}$ tabel validitasnya adalah 0,344 . Berdasarkan $r$ tabel tersebut, maka instrumen penelitian dapat dikatakan valid jika $r$ hitung $>0,344$ dan instrumen penelitian tidak valid jika $r$ hitung $<0,344$. Hasil uji validitas dalam penelitian ini dinyatakan pada tabel berikut ini 
Tabel 2. Hasil uji validitas penelitian

\begin{tabular}{|c|c|c|c|}
\hline Indikator & $\begin{array}{c}\text { r } \\
\text { hitung }\end{array}$ & $\begin{array}{c}\text { r } \\
\text { tabel }\end{array}$ & Keterangan \\
\hline P 1 & 0,824 & 0,344 & Valid \\
\hline P 2 & 0,888 & 0,344 & Valid \\
\hline P 3 & 0,843 & 0,344 & Valid \\
\hline P 4 & 0,788 & 0,344 & Valid \\
\hline P 5 & 0,912 & 0,344 & Valid \\
\hline P 6 & 0,823 & 0,344 & Valid \\
\hline P 7 & 0,863 & 0,344 & Valid \\
\hline P 8 & 0,709 & 0,344 & Valid \\
\hline P 9 & 0,648 & 0,344 & Valid \\
\hline P 10 & 0,866 & 0,344 & Valid \\
\hline P 11 & 0,940 & 0,344 & Valid \\
\hline P 12 & 0,575 & 0,344 & Valid \\
\hline P 13 & 0,940 & 0,344 & Valid \\
\hline P 14 & 0,768 & 0,344 & Valid \\
\hline P 15 & 0,571 & 0,344 & Valid \\
\hline
\end{tabular}

Pernyataan dari tabel 2 di atas dapat disimpulkan bahwa semua indikatornya, $\mathrm{r}$ hitung $>\mathrm{r}$ tabel. Sehingga dalam instrumen penelitian dapat dinyatakan valid dari uji validitasnya yang memiliki $r$ tabel 0,344 .

Tabel 3. Uji reliabilitas

\begin{tabular}{|c|c|}
\hline $\begin{array}{c}\text { Cronbach's } \\
\text { Alpha }\end{array}$ & N of Items \\
\hline 0.956 & 15 \\
\hline
\end{tabular}

Uji realibitlitas digunakan untuk mengetahui kredibilitas data yang diambil dalam suatu penelitian (Yusup, 2018). Dalam penelitian ini, uji realibilitas menggunakan Alpha Cronbach. Instrumen penelitian dikatakan reliabel jika nilai koefisien Alpa Cronbach lebih dari 0,70 $\left(n_{\uparrow}>0,70\right)$ (Yusup, 2018). Pernyataan dari tabel 3 dapat disimpulkan bahwa nilai koefesien Alpa Cronbach adalah 0,956 yang lebih besar dari 0,70. Jadi, disimpulkan bahwa data instrumen penelitian tersebut reliabel.

\section{Analisis dan Hasil Penelitian}

Guru dan terapis pada sekolah inklusi, sekolah khusus, dan lembaga terapis di Jawa Timur yang telah menerapkan metode PECS sebesar 30 responden, yaitu sejumlah 79\%. Hasil dari 30 responden yang menerapkan metode PECS di Jawa Timur diuraikan sebagai berikut.

Indikator 1 atau pernyataan 1 (P1) berisi pernyataan terkait memiliki pemahaman teknis tentang penerapan metode PECS, diisi oleh 28 responden menjawab "Ya" dan 2 responden menjawab "Tidak". Dalam hal ini, persentase responden sebesar 93\% memiliki pemahaman teknis tentang penerapan metode PECS dan 7\% tidak memiliki pemahaman teknis tentang penerapan metode PECS.

Indikator 2 atau pernyataan 2 (P2) berisi pernyataan terkait menerapkan fase atau tahapan PECS pertama yaitu latihan berkomunikasi tahap awal yaitu menukarkan kartu pada benda, diisi 
oleh 29 responden menjawab "Ya" dan 1 responden menjawab "Tidak". Dalam hal ini, persentase responden sebesar 97\% menerapkan fase atau tahapan pertama dan 3\% tidak menerapkan fase atau tahapan pertama.

Indikator 3 atau pernyataan 3 (P3) berisi pernyataan terkait menerapkan fase atau tahapan PECS kedua yaitu memberikan jarak dan adanya persistensi atau komunikasi berulang dalam menukarkan gambar dengan benda, diisi oleh 25 responden menjawab "Ya" dan 5 responden menjawab "Tidak". Dalam hal ini, persentse responden sebesar 83\% menerapkan fase atau tahapan PECS kedua dan 17\% tidak menerapkan fase atau tahapan PECS kedua.

Indikator 4 atau pernyataan 4 (P4) berisi terkait menerapkan fase atau tahapan PECS ketiga (a) yaitu membedakan dua benda atau gambar yang disukai dan tidak disukai dalam berkomunikasi untuk mendapatkan benda, diisi oleh 24 responden menjawab "Ya" dan 6 responden menjawab "Tidak". Dalam hal ini, persentase responden sebesar $80 \%$ menerapkan fase atau tahapan PECS ketiga (a) dan 20\% tidak menerapkan fase atau tahapan PECS ketiga (a).

Indikator 5 atau pernyataan 5 (P5) berisi menerapkan fase atau tahapan PECS ketiga (b) yaitu membedakan dua gambar benda atau gambar yang sama-sama disukai dalam berkomunikasi untuk mendapatkan benda, diisi oleh 28 responden menjawab "Ya" dan 2 responden menjawab "Tidak". Dalam hal ini, persentase responden sebesar 93\% menerapkan fase atau tahapan PECS ketiga (b) dan 7\% tidak menerapkan fase atau tahapan PECS ketiga (b).

Indikator 6 atau pernyataan 6 (P6) berisi menerapkan fase atau tahapan PECS keempat yaitu pembentukkan struktur kalimat pada anak untuk mendapatkan benda, diisi oleh 25 responden menjawab "Ya" dan 5 responden menjawab "Tidak". Dalam hal ini, persentase responden sebesar $83 \%$ menerapkan fase atau tahapan PECS keempat dan 17\% tidak menerapkan fase atau tahapan PECS keempat.

Indikator 7 atau pernyataan 7 (P7) berisi menerapkan fase atau tahapan PECS kelima yaitu memberikan kesempatan kepada anak merespon pertanyaan seperti "Apa yang kamu inginkan?" dengan membentuk struktur kalimat dalam berkomunikasi untuk mendapatkan benda, diisi oleh 27 responden menjawab "Ya" dan 3 responden menjawab "Tidak". Dalam hal ini, persentase responden sebesar 90\% menerapkan fase atau tahapan metode PECS kelima dan 10\% tidak menerapkan fase atau tahapan metode PECS kelima.

Indikator 8 atau pernyataan 8 (P8) berisi menerapkan fase atau tahapan PECS keenam yaitu memberikan kesempatan untuk siswa berkomentar terhadap sesuatu yang dilihatnya atau suatu pernyataan, diisi oleh 22 responden menjawab "Ya" dan 8 responden menjawab "Tidak". Dalam hal ini, persentase responden sebesar 73\% menerapkan fase atau tahapan PECS keenam dan 27\% tidak menerapkan fase atau tahapan PECS keenam.

Indikator 9 atau pernyataan 9 (P9) berisi melaksanakan prosedur metode PECS sesuai dengan tahapannya, diisi oleh 18 responden menjawab "Ya" dan 12 responden menjawab "Tidak". Dalam hal ini, persentase responden sebesar 60\% melaksanakan prosedur PECS sesuai dengan tahapannya dan 40\% tidak melaksanakan metode PECS sesuai dengan tahapannya.

Indikator 10 atau pernyataan 10 (P10) berisi metode PECS cocok diterapkan untuk mengembangkan keterampilan komunikasi anak spektrum autisme, diiisi oleh 29 responden menjawab "Ya" dan 1 responden menjawab "Tidak". Dalam hal ini, persentase responden sebesar 97\% merasa metode PECS cocok diterapkan untuk mengembangkan keterampilan komunikasi anak spektrum autime dan 3\% merasa kurang cocok jika metode PECS diterapkan untuk mengembangkan keterampilan komunikasi anak spektrum autisme. 
Indikator 11 atau pernyataan 11 (P11) berisi terkait pengalaman pribadi, metode PECS dapat meningkatkan keterampilan komunikasi anak spektrum autisme, diiisi oleh 30 reesponden menjawab "Ya". Dalam hal ini, persentase responden sebesar 100\% merasa metode PECS dapat digunakan untuk meningkatkan keterampilan komunikasi anak spektrum autisme.

Indikator 12 atau pernyataan 12 (P12) beisi terkait tidak adanya kendala dalam pemberian metode PECS untuk anak spektrum autisme, diisi oleh 16 reponden menjawab "Ya" dan 14 reponden menjawab "Tidak". Dalam hal ini, persentase responden sebesar 53\% merasa tidak adanya kendala dalam pemberian metode PECS untuk anak spektrum autisme dan $47 \%$ merasa adanya kendala dalam pemberian metode PECS untuk anak spektrum autisme.

Indikator 13 atau pernyataan 13 (P13) berisi terkait alat bantu media visualisasi untuk penerapan metode PECS mudah ditemukan dan harga terjangkau seperti tanda, gambar, dan/atau simbol, diisi oleh 30 responden menjawab "Ya". Dalam hal ini, responden sebesar 100\% merasa alat bantu media visualisasi untuk penerapan metode PECS mudah ditemukan dan harga terjangkau seperti tanda, gambar, dan simbol.

Indikator 14 atau pernyataan 14 (P14) berisi terkait selalu memberikan reward berupa hadiah kepada anak setelah melakukan apa yang diperintahkan, diisi oleh 26 responden menjawab "Ya" dan 4 responden menjawab "Tidak". Dalam hal ini, persentase responden sebesar 87\% selalu memberikan reward berupa hadiah kepada anak setelah melakukan apa yang diperintahkan dan 13\% tidak selalu memberikan reward berupa hadiah kepada anak setelah melakukan apa yang diperintahkan.

Indikator 15 atau pernyataan 15 (P15) berisi terkait memberikan punishment atau hukuman seperti tidak memberikan sesuatu yang disukai saat anak tidak mengikuti apa yang diperintahkan, diisi oleh 19 responden menjawab "Ya" dan 11 responden menjawab "Tidak". Dalam hal ini, persentase responden perbandingan sebesar 63\% memberikan memberikan punishment atau hukuman seperti tidak memberikan sesuatu yang disukai saat anak tidak mengikuti apa yang diperintahkan dilakukan setengah atas populasi dan sisanya $37 \%$ tidak memberikannya.

Tabel 4. Rekapitulasi Persentase Hasil Survei

\begin{tabular}{|c|c|c|}
\hline Indikator & Ya (\%) & Tidak (\%) \\
\hline P1 & $93 \%$ & $7 \%$ \\
\hline P2 & $97 \%$ & $3 \%$ \\
\hline P3 & $83 \%$ & $17 \%$ \\
\hline P4 & $80 \%$ & $20 \%$ \\
\hline P5 & $93 \%$ & $7 \%$ \\
\hline P6 & $83 \%$ & $17 \%$ \\
\hline P7 & $90 \%$ & $10 \%$ \\
\hline P8 & $73 \%$ & $27 \%$ \\
\hline P9 & $60 \%$ & $40 \%$ \\
\hline P10 & $97 \%$ & $3 \%$ \\
\hline P11 & $100 \%$ & $0 \%$ \\
\hline P12 & $53 \%$ & $47 \%$ \\
\hline P13 & $100 \%$ & $0 \%$ \\
\hline P14 & $87 \%$ & $13 \%$ \\
\hline
\end{tabular}




\begin{tabular}{|c|c|c|}
\hline Indikator & Ya (\%) & Tidak (\%) \\
\hline P15 & $63 \%$ & $37 \%$ \\
\hline
\end{tabular}

\section{B. PEMBAHASAN}

Berdasarkan penelitian terhadap 38 responden, terdapat 79\% yang telah menerapkan metode PECS di sekolah inklusi, sekolah khusus, dan lembaga terapi atau sebesar 30 responden. Dari hasil survei yang didapatkan dari 30 responden tersebut, yang memiliki pemahaman teknis tentang tahapan metode PECS dari fase 1-6 sebesar 93\%. Menurut responden, tahapan dalam metode PECS yang sering dilakukan adalah fase pertama, yaitu anak dilatih untuk berkomunikasi dengan sekitarnya dengan cara mengambil gambar yang disukainya dari guru atau terapis kepada teman sebayanya agar dapat berinteraksi lebih dekat. Menurut Goa \& Derung (2017), fase atau tahapan metode PECS pertama bertujuan untuk melatih awal ketertarikan komunikasi anak dengan lingkungannya. Hal ini dapat dilakukan dengan cara guru atau terapis memberikan perintah kepada anak spektrum autisme untuk mengambil dan meletakkan benda atau gambar sebagai media penerapan metode PECS. Anak cenderung tertarik dikarenakan melihat gambar yang menarik dan dia termasuk pembelajar visual (Putri et al., 2018). Penjelasan tersebut dapat membantu anak spektrum autisme yang terhambat dalam memahami komunikasi secara verbal dan menjadi komunikator dalam berkomunikasi secara tatap muka serta adanya kontak mata (Hartati \& Hardiansyah, 2019). Hasil survei dalam penelitian menyebutkan bahwa guru atau terapis yang melakukan prosedur metode PECS sesuai dengan tahapannya hanya 60\%. Hal ini dikarenakan, penerapan metode PECS disesuaikan dengan kebutuhan dan kemampuan yang dimiliki anak spektrum autisme.

Hasil dari survei menyebutkan bahwa sebagian besar guru dan terapis di Jawa Timur merasa metode PECS sesuai dengan anak spektrum autisme dan dapat meningkatkan keterampilan komunikasinya sebesar 98,5\%. Dalam penelitian Hu \& Lee (2019), adanya peningkatan komunikasi terhadap anak spektrum autisme setelah diberikan intervensi secara berkala dan intens dari fase ke-1 hingga ke-6. Anak spektrum autisme dapat melakukan komunikasi verbal secara spontan dari yang sebelumnya kurang dapat berkomunikasi dengan orang lain. Penelitian lain dari Vistasari \& Patria (2019), mengatakan bahwa terdapat peningkatan keterampilan komunikasi terstruktur yang terjadi terhadap 2 anak spektrum autisme. Hal ini dibuktikan adanya peningkatan dari hanya dapat berkomunikasi beberapa kata serta pengucapannya terbalik menjadi mampu mengucapkan struktur kalimat S-P-O setelah diberikan intervensi menggunakan metode PECS selama 11-12 kali pertemuan.

Berdasarkan penelitian, guru dan terapis tidak menemui kendala dalam menerapkan metode PECS sebesar 53\% dan menyampaikan bahwa media yang digunakan mudah ditemukan serta terjangkau sebesar $100 \%$. Kendala dalam meningkatkan keterampilan komunikasi anak spektrum autisme yaitu anak yang sulit diajak berkomunikasi serta berkontak mata dengan orang lain. Keberhasilan dalam memberikan intervensi menggunakan metode PECS kepada anak spektrum autisme dibantu dengan media visualisasi seperti gambar. Hal ini terlihat dalam penelitian yang disebutkan sebelumnya bahwa anak spektrum autisme yang awalnya kesulitan dalam berbicara terstruktur setelah diberikan intervensi menggunakan metode PECS dapat berkembang komunikasinya menjadi lebih terstruktur. Anak dengan spektrum autisme kesulitan menerima informasi secara verbal dan terbantu adanya penerapan metode PECS yang menggunakan media pertukaran kartu bergambar dalam melatih keterampilan komunikasinya (Vistasari \& Patria, 2019). 
Selain itu, terdapat penelitian di Yayasan Nanda Delisa Kabupaten Bondowoso bahwa media visual berupa kartu bergambar makanan dan minuman yang disukainya dapat meningkatkan keterampilan komunikasi anak spektrum autisme. Anak dapat mengubah kebiasaanya dari respon yang lambat menjadi lebih cepat ketika diberikan intruksi makanan dan minuman yang disukainya (Wasi'ah, 2018). Selain itu, media visualisasi seperti gambar dan simbol dapat membantu karakteristik belajar visual anak spektrum autisme dalam meningkatkan keterampilan komunikasinya.

Hasil survei menyebutkan bahwa guru memberikan reward sebesar $87 \%$, tetapi masih ad yang memberikan hukuman sebesar 63\%. Memberikan motivasi semangat belajar anak spektrum autisme dalam mengembangkan keterampilan komunikasinya sangat dibutuhkan, diantaranya dapat diberikan mainan atau makanan serta minuman kesukaannya (Goa \& Derung, 2017). Hal tersebut dapat diberikan setelah anak menyelesaikan apa yang diperintahkan guru atau terapis terhadapnya. Menurut Hu \& Lee (2019), anak dapat diberikan pujian jika mampu memilih gambar yang benar dan diberi halangan jika memilih gambar yang salah. Selain itu, menurut Wasi'ah (2018) dalam proses pelaksanaan metode PECS, guru atau terapis tidak akan memberikan bantuan sebelum anak spektrum autisme mampu menunjuk apa yang dia inginkan. Penjelasan tersebut dimaksudkan sebagai hukuman positif terhadap anak untuk melatih kedisiplinan. Jika anak spektrum autisme tidak mengikuti apa yang diperintahkan, keinginannya tidak akan diberikan.

\section{PENUTUP}

\section{Simpulan}

Berdasarkan hasil penelitian, dapat disimpulkan sebagai berikut.

1. Guru dan terapis di Jawa Timur yang telah menerapkan metode PECS sebesar 79\%.

2. Sebagian besar guru dan terapis di Jawa Timur sudah menerapkan PECS fase ke-1 sampai fase ke-6 dengan rentang 73\%-97\% dan yang menerapkan prosedur PECS sesuai tahapanannya. sejumlah $60 \%$.

3. Sebagian besar guru dan terapis di Jawa Timur merasa PECS sesuai dengan anak spektrum autism (97\%) dan dapat meningkatkan keterampilan komunikasinya (100\%).

4. Sebagian besar guru dan terapis tidak menemui kendala dalam penerapan PECS (53\%), dan media mudah ditemukan dan terjangkau (100\%).

5. Dalam penerapan PECS, guru dan terapis di Jawa Timur yang memberikan rewards sebesar $87 \%$, tetapi masih ada yang memberikan hukuman sebesar $63 \%$.

\section{Saran}

Berdasarkan hasil penelitan tentang penerapan Metode PECS Terhadap Keterampilan Komunikasi Anak Spektrum Autisme di sekolah inklusi dan sekolah khusus serta lembaga terapi terapi pada wilayah Provinsi Jawa Timur dapat diberikan saran berupa

1. Bagi guru atau terapis autis

Menjadikan pengetahuan bagi guru atau terapis autis bahwa metode PECS telah diterapkan dan cocok untuk meningkatkan keterampilan komunikasi anak spektrum autisme. Selain itu, penelitian ini dapat sebagai pedoman melaksanakan metode PECS untuk meningkatkan keterampilan komunikasi autisme sesuai dengan tahapan yang terdapat di dalam indikator penelitian. 


\section{Bagi Peneliti Selanjutnya}

Peneliti lain dapat mengadakan penelitian dengan topik serupa, namun menggunakan variasi yang berbeda, misalnya subyek yang berbeda, teknik pengumpulan data yang berbeda, atau jangkauan penelitian lebih luas.

\section{DAFTAR PUSTAKA}

Alsayedhassan, B., Banda, D. R., \& Griffin-Shirley, N. (2016). A Review of Picture Exchange Communication Interventions Implemented by Parents and Practitioners. Child and Family Behavior Therapy, 38(3), 191-208. https://doi.org/10.1080/07317107.2016.1203135

Amka, A. (2017). Implementasi Pendidikan Karakter Inklusi Bagi Anak Berkebutuhan Khusus Di Sekolah Reguler. Madrosatuna: Journal of Islamic Elementary School, 1(1), 1. https://doi.org/10.21070/madrosatuna.v1i1.1206

Asep Sunandar, A., Sunandar, A., Indreswari, H., Efendi, M., Dian Firdiana, A., \& Lailiyah, N. (2019). The Use of Visual Support of PECS and Schedule Based on the Characteristics of Student with Autism. 382(Icet), 559-564. https://doi.org/10.2991/icet-19.2019.140

Daroni, G. A., Solihat, G., \& Salim, A. (2018). Manajemen Pendidikan Khusus di Sekolah Luar Biasa Untuk Anak Autis. Kelola: Jurnal Manajemen Pendidikan, 5(2), 196-204. https://doi.org/10.24246/j.jk.2018.v5.i2.p196-204

Goa, L., \& Derung, T. N. (2017). Komunikasi Ekspresif Dengan Metode Pecs Bagi Anak Dengan Autis. Jurnal Nomosleca, 3(2). https://doi.org/10.26905/nomosleca.v3i2.2037

Hartati, M. S., \& Hardiansyah. (2019). Role of Parents in the Success of Children Autism. AlBidayah : Jurnal Pendidikan Dasar Islam, XI(2).

Heryati, E., \& Ratnengsih, E. (2017). PENGGUNAAN METODE PECS (Picture Exchange Communication System) UNTUK MENINGKATKAN KEMAMPUAN KOMUNIKASI ANAK AUTIS. Pedagogia, 15(1), 30. https://doi.org/10.17509/pedagogia.v15i1.6558

$\mathrm{Hu}, \mathrm{X} .$, \& Lee, G. (2019). Effects of PECS on the Emergence of Vocal Mands and the Reduction of Aggressive Behavior Across Settings for a Child With Autism. Behavioral Disorders, 44(4), 215-226. https://doi.org/10.1177/0198742918806925

Jurgens, A., Anderson, A., \& Moore, D. W. (2019). Maintenance and generalization of skills acquired through picture exchange communication system (PECS) training: a long-term follow-up. Developmental Neurorehabilitation, 22(5), 338-347. https://doi.org/10.1080/17518423.2018.1503619

Koesdiningsih, T., Basoeki, L., Febriyana, N., \& Maramis, M. M. (2019). Hubungan Penggunaan Visual Support Terhadap Perbaikan. 7, 77-84. https://doi.org/10.20473/jbe.v7i12019.

Marhamah. (2019). Pola Komunikasi anak autis: studi etnografi komunikasi pada keterampilan interaksi anak autis di Sekolah Cinta Mandiri Lhokseumawe. Jurnal Al-Bayan, 25(1), 1-34.

Putri, C. R. R., Hastuti, W. D., \& Adi, E. P. (2018). The Influence the Picture Exchange Communication System Method toward The Communication Ability of Autistic Child. Journal of ICSAR, 2(2), 180-185. https://doi.org/10.17977/um005v2i22018p180

Rega, A., Somma, F., \& Simeoli, R. (2018). a Review of Scientific Studies on the Effectiveness of Speech-Generating Devices To Stimulate Communication in People With Autism. ICERI2018 Proceedings, 1(November), 5160-5165. https://doi.org/10.21125/iceri.2018.2182

Ritonga, S. A., \& Hasibuan, E. J. (2016). Komunikasi Interpersonal Guru Dan Siswa Dalam 
Mengembangkan Bakat Dan Kreativitas Anak Autis Di Slb Taman Pendidikan Islam (Tpi). JURNAL SIMBOLIKA: Research and Learning in Communication Study, 2(2). https://doi.org/10.31289/simbollika.v2i2.1030

Sugiyono. (2016). Metode Penelitian Kuantitatif, Kualitatif, dan R\&D (23rd ed.). Alfabeta.

Vistasari, R., \& Patria, B. (2019). Program PECS (Picture Exchange Communication System) untuk Meningkatkan Kemampuan Berbicara Terstruktur pada Anak Autis. Gadjah Mada Journal of Professional Psychology (GamaJPP), 5(1), 94. https://doi.org/10.22146/gamajpp.48590

Wasi'ah, M. (2018). Pengaruh penggunaan metode pecs terhadap kemampuan komunikasi anak autis di yayasan nanda delisha rumah abk kabupaten bondowoso. 75-82.

Wiggins, L. D., Rice, C. E., Barger, B., Soke, G. N., Lee, L. C., Moody, E., Edmondson-Pretzel, R., \& Levy, S. E. (2019). DSM-5 criteria for autism spectrum disorder maximizes diagnostic sensitivity and specificity in preschool children. Social Psychiatry and Psychiatric Epidemiology, O(0), 0. https://doi.org/10.1007/s00127-019-01674-1

Yusup, F. (2018). Uji Validitas dan Reliabilitas Instrumen Penelitian Kuantitatif. Jurnal Tarbiyah : Jurnal Ilmiah Kependidikan, 7(1), 17-23. https://doi.org/10.18592/tarbiyah.v7i1.2100 